\title{
PENAMPILAN DOSEN KEPERAWATAN BERDASARKAN PENILAIAN MAHASISWA STIKES DIRGAHAYU SAMARINDA
}

\author{
Bernarda Teting ${ }^{1}$, Yani $^{2}$, Yulietha Lehyun ${ }^{3}$, Aldi Pratama ${ }^{4}$, Afdaliah Jusnanda ${ }^{5}$ \\ Prodi DIII Keperawatan STIKES Dirgahayu Samarinda ${ }^{1,2,3,4,5}$ \\ Jl. Pasundan No. 21 Kelurahan Jawa Kota Samarinda \\ e-mail: bernardateting@gmail.com
}

\begin{abstract}
Dosen dalah pendidik profesional dan ilmuwan dengan tugas utama mentransformasikan, mengembangkan, dan menyebarluaskan ilmu pengetahuan, teknologi, dan seni melalui pendidikan, penelitian, dan pengabdian kepada masyarakat. Tujuan dari penelitian ini adalah pertama, untuk mengetahui tingkat kemampuan profesional dosen, kedua untuk mengetahui gambaran hubungan interpersonal dosen dengan mahasiswa dan terakhir untuk memberi gambaran tentang kualitas dosen keperawatan di STIKES Dirgahayu Samarinda. Berdasarkan tujuan penelitian yang ada, rancangan penelitian yang digunakan adalah studi deskriptif. Sampel penelitian ini adalah total populasi dari mahasiswa tingkat 2 dan 3 keperawatan di Program Studi D-3 Keperawatan dengan jumlah 164 orang. Hasil penelitian menunjukkan sebagian besar dosen di Program Studi D-3 Keperawatan memiliki kemampuan profeional baik dan baik sekali tergambar dalam penelitian 57,9\% menguasai materi yang diaarkan dengan baik dan 26,7\% baik sekali. Juga sistimatika penyajian materi $69,3 \%$ baik dan $20,1 \%$ baik sekali menurut mahasiswa. Hubungan interpersonal dosen dengan mahasiswa, pada umumnya responden mengatakan ya, terbukti paha hasil penelitian $95,1 \%$ dosen dapat menciptakan suasana belaar yang kondusif, dosen juga memberikan kebebasan kepada mahasiswa untuk mengaukan pendapat dan pertanaan terlihat dari penelitian yaitu $98,8 \%$ responden mengatakan ya. Kualitas personal, responden pada umumnya atau 99,4\% dosen memiliki kemampuan berkomunikasi, 99,4\% setuju dengan penampilan dosen, serta $98,2 \%$ responden mengatakan dosen memiliki keluwesan/fleksibilitas dalam mengajar.
\end{abstract}

Key Words —Penampilan, Kualitas, Interpersonal, Dosen

\section{PENDAHULUAN}

Dosen dalah pendidik profesional dan ilmuwan dengan tugas utama mentransformasikan, mengembangkan, dan menyebarluaskan ilmu pengetahuan, teknologi, dan seni melalui pendidikan, penelitian, dan pengabdian kepada masyarakat. Kualifikasi dan kompetensi dosen ditentukan dan diatur oleh Undang Undang. UU Nomor 14 tahun 2005 Tentang Guru dan Dosen, dijelaskan bahwa dosen wajib memiliki kualifikasi akademik, kompetensi, sertifikat pendidik, sehat jasmani dan rohani, dan memenuhi kualifikasi lain yang dipersyaratkan satuan pendidikan tinggi tempat bertugas, serta memiliki kemampuan untuk mewujudkan tujuan pendidikan nasional. Untuk menjadi dosen sekurang-kurangnya harus memenuhi dua standart, yaitu standar kualifikasi dan kompetensi. Standar kualifikasinya adalah jenjang pendidikan sebagaimana ditetapkan dalam dalam 
stanadar pendidikan tinggi. Untuk mengajar di program SI, maka dosen harus lulus pendidikan S2, dan untuk mengajar di program Pascasarjana untuk program S2 maka harus dosen lulusan program S3 dan untuk program S3 harus dosen yang bergelar guru besar.

Standart kompetensi, yaitu: pertama, kompetensi pedagogis atau kemampuan dosen pengelola pembelajaran. Kedua, kompetensi kepribadian atau standar kewibawaan, kedewasaan, dan keteladanan. Ketiga, kompetensi profesional atau kemampuan dosen untuk menguasai konten dan metodologi pembelajaran. Keempat, kompetensi sosial atau kemampuan dosen untuk melakukan komunikasi sosial, baik kepada mahasiswa maupun masyarakat.

Idealnya kemampuan dan keahlian itu harus terus diasah dan dikembangkan oleh perguruan tinggi dari waktu ke waktu, agar dosen sebagai pilar perguruan tinggi selalu memiliki keunggulan kompetitif dan kualitas demi tercapainya tujuan perguruan tinggi. Peningkatan kualitas dosen di perguruan tinggi dapat dilakukan dengan berbagai metode dan cara, diantaranya dengan memberikan program pendidikan dan pelatihan secara berkesinambungan, memperbaiki metode dan strategi pengembangan dosen melalui pemenuhan kompetensi sesuai bidangnya yang dilandasi pengetahuan, keterampilan dan budaya kerja yang positif, atau dengan mengirimkan dosen ke berbagai perguruan tinggi terkemuka baik di dalam maupun di luar negeri untuk melanjutkan ke jenjang pendidikan formal yang lebih tinggi maupun untuk mendapatkan keahlian khusus yang diperlukan perguruan tinggi, Dengan demikian dosen yang ada diharapkan mampu berkarya dan selalu siap untuk menyesuaikan diri terhadap perubahan.

\section{METODE}

Tujuan dari penelitian ini adalah pertama, untuk mengetahui tingkat kemampuan profesional dosen, kedua untuk mengetahui gambaran hubungan interpersonal dosen dengan mahasiswa dan terakhir untuk memberi gambaran tentang kualitas dosen keperawatan di STIKES Dirgahayu Samarinda. Lokasi penelitian yaitu STIKes Dirgahayu samarinda jln. Pasundan no, 21 Samarinda. Waktu penelitian dimulai bulan Juli dan berakhir pada bulan Desember 2020.

Populasi penelitian ini adalah mahasiswa tingkat 2 dan 3 keperawatan Program Studi D-3 Keperawatan STIKes Dirgahayu Samarinda. Sampel penelitian ini adalah total populasi dari mahasiswa tingkat 2 dan 3 keperawatan di Program Studi D-3 Keperawatan dengan jumlah 164 orang. Penelitian deskriktif ini memiliki satu variable yaitu penampilan dosen Progran Studi D-3 keperawatan dengan tiga indicator yaitu kemampuan profesional dosen, hubungan interpersonal dosen dengan mahasiswa dan kualitas personal. Data dikumpulkan dengan cara menyebarkan formulir di google form melalui link google ke semua semua mahasiswa diploma tiga Keperawatan.

Pada penelitian ini data dikumpulkan dengan menggunakan google form. Setelah data dikumpulkan selanjutnya dilakukan proses analisa statistik deskriptif proporsi presentase. Setelah hasil scoring terkumpul kemudian ditabulasi dan dianalisis secara statistik deskriptif proporsi presentase, penyajian menggunakan deskriptif dan tabel distribusi yang dikonfirmasikan dalam bentuk presentase.

\section{HASIL}

Penampilan dosen STIKES Dirgahayu Samarinda khususnya diploma tiga keperawatan tergambar sebagaimana di deskripsi dibawah ini 
sesuai dengan hasil pengisian kuesioner dari 164 responden.

Tabel 1 Kemampuan Profesional

\begin{tabular}{llcccc}
\hline $\mathrm{N}$ & Kemampuan & $\begin{array}{c}\text { Baik } \\
\text { sekali }\end{array}$ & Baik & Cukup & Kurang \\
\hline 1 & $\begin{array}{l}\text { Penguasaan } \\
\text { materi yang } \\
\text { diajarkan } \\
2\end{array}$ & 26,7 & 57,9 & 13,4 & 2 \\
\hline & $\begin{array}{l}\text { Sistimatika } \\
\text { penajian }\end{array}$ & 20,1 & 69,3 & 11,6 & 0 \\
3 & $\begin{array}{l}\text { materi } \\
\text { Cara/metode } \\
\text { mengajar }\end{array}$ & 20,7 & 65,5 & 11,6 & 2,2 \\
4 & $\begin{array}{l}\text { Persiapan } \\
\text { mengajar }\end{array}$ & 27,4 & 60,4 & 12,2 & 0 \\
5 & $\begin{array}{l}\text { Kemampuan } \\
\text { membuat } \\
\text { media } \\
\text { pengajaran }\end{array}$ & 23,8 & 65,2 & 11 & 0 \\
\hline
\end{tabular}

Berdasarkan data pada tabel diatas dapat kita simpulkan bahwa dosen diploma tiga Keperawatan di STIKES Dirgahayu Samarinda memiliki kemampuan profesional sebagian besar baik dan baik sekali. Secara terperinci tergambar pada masing-masing kemampuan yaitu 1) Penguasaan materi yang diajarkan baik sekali memperoleh $26,7 \%$, sedangkan dosen yang memiliki penguasaan materi baik $57,9 \%$ dari 164 mahasiswa, namun masih ada mahasiswa ang mengatakan dosen kurang memahami penguasaan materi. 2) Dosen dalam mengajar dan menyajikan materi secara sistimatika, menurut mahasiswa $69.3 \%$ menyatakan baik, dan 20,1\% menyatakan baik sekali, dengan demikian masih ada mahasiswa yang mengatakan cukup, inilah yang mendapat perhatian dari dosen dan institusi. 3) Cara/metode mengajar, dari 164 orang mahasiswa, $65,5 \%$ mengatakan baik dan 20,7\% mengatakan sangat baik. Namun yang menjadi perhatian adalah masih ada dosen yang menggunakan metode mengajar cukup dan bahkan kurang, hal ini mempengaruhi tingkat pemahaman mahasiswa. 4) menurut mahasiswa, dosen keperawatan sebagain besar melakukan persiapan mengajar dengan baik dan sangat baik terlihat dalam tabel diatas yaitu $87,8 \%$ baik dan sangat baik. 5) kemampuan membuat media pengajaan, berdasarkan penilaian mahasiswa $60.4 \%$ baik dan $27,4 \%$ mengatakan sangat baik, tetapi masih ada dosen yang belum bisa menggunakan media pembelajaran dengan baik.

a. Hubungan interpersonal dengan mahasiswa.

Hubungan interpersonal antara dosen dengan mahasiswa sangat penting baik dalam proses pembelajaran maupun di luar proses tersebut. Hubungan interpersonal yang baik akan mendukung motivasi belajar, suasana belajar, dan merasa dihargai sebagai manusia.

$\begin{array}{llr}\text { Hasil } & \text { penelitian tentang } \\ \text { hubungan } & \text { interpersonal } \\ \text { dengan } & \text { dosen }\end{array}$
dengan mahasiswa dijelaskan sebagai berikut. Dari 164 mahasiswa yang menjadi sampel, $95,1 \%$ mengatakan dosen dapat menciptaan suasana belajar yang kondusif. 95,7\% mengatakan dosen dalam proses pembelajaran dapat membangkitkan motivasi belajar mahasiswa. Bagaimana hubungan dosen dengan mahasiswa apakah dosen membatasi hubungan dengan mahasiswa? Ternyata 50\% mahasiswa menjawab bahwa dosen membatasi hubungan dengan mahasiswa. Dosen keperawatan sangat baik dalam memberi kebebasan kepada mahasiswa untuk mengajukan pendapat dan pertanyaan dengan jumlah $98,8 \%$ dari 164 mahasiswa. Mahasiswa keperawatan juga mengatakan sebagian besar dosen keperawatan dalam pembejaran telah menghargai mahasiswa dibuktikan dengan jumlah 90,4\% dari 164 orang mahasiswa. 95,7\% atau secara umum dosen sangat respek terhadap permasalahan yang dialami mahasiswa. 
b. Kualitas personal

Berdasarkan hasil penelitian, kualitas personal dosen dapat digambarkan dalam beberapa indikator berikut seperti; 1) Pengetahuan, pengalaman/wawasan yang berkaitan dengan bahan yang diajarkan $\quad 97 \% \quad$ responden mengatakan ya, dan 3\% mengatakan tidak. 2) responden mengatakan bahwa dosen memiliki semangat/ gairah dalam mengajar dibuktikan dalam hasil penelitian $96,3 \%$ dari 164 orang responden. 3) kemampuan berkomunikasi/berbicara

menunjukkan jumlah $99,4 \%$ responden mengatakan dosen memiliki kemampuan berkomunikasi/berbicara.

Mengenai

penampilan/kerapihan/kebersihan dosen, 99,4\% responden mengatakan ya dalam arti setuju dengan penapilan dosen. 5) 90,2\% mahasiswa mengatakan dosen bisa kontrol diri pada saat marah. 6) dosen keperawatan memiliki keluwesan/fleksibilitas dalam mengajar dibuktikan dengan jumlah $98,2 \%$ menjawab ya atau setuju. 7) di dalam proses pembelajaran perlu diselingi dengan rasa humor, dari hasil penelitian $84,1 \%$ mahasiswa mengatakan dosen memiliki homor. 8) dosen diharapkan memiliki kemampuan menerima kritik dari mahasiswa, hasil penelitian menunjukkan $92,7 \%$ responden mengtakan ya. 9) menurut responden 97,6\% mengatakan bahwa dosen memiliki kemampuan memberi kritik. 10) Dalam penggunaan bahasa yang tepat dalam mengajar 100\% responden mengatakan ya. 11) bagaimana kemampuan dosen dalam menciptakan kreativitas mengajar? 95,7\% responden mengatakan dosen memiliki kemampuan menciptakan kreativitas mengajar.

\section{KESIMPULAN DAN SARAN}

\section{Kesimpulan}

Dari hasil penelitian dapat tergambar bahwa penampilan dosen diploma tiga memiliki kemampuan professional, hubungan interpersonal dosen dengan mahasiswa sebagian besar baik. dan kualitas dosen keperawatan dalam memberi kuliah atau mengajar rata-rata menunjukkan kualitas yang baik dan sangat baik. Namun demikian masih ada sebagian kecil yang memiliki kemampuan profesional, juga hubungan interpersonal dosen dengan mahasiswa masih ada yang belum sesuai harapan mahasiswa. Selain itu kualitas dosen dalam memberi kuliah juga masih ada beberapa belum sesuai harapan.

\section{Saran}

Bagi dosen STIKES umumnya dan dosen diploma tiga keperawatan khususnya dapat mempertahankan ketrampilan yang sudah baik, dan dapat meningkatkan ketrampilan yang masih kurang melalui pengembangan diri yang terus menerus baik untuk meningkatkan profesionalime, hubungan interpersonal dan kualitas diri sebagai dosen. Bagi manajemen STIKES Dirgahayu Samarinda, semoga dapat memfasilitasi dengan memberi kesempatan kepada dosen untuk mengembang diri melalui pelatihan dan atau pendidikan berkelanjutan.

DAFTAR PUSTAKA

Bangun Joko Laksono. 2015. Kualifikasi dan Kompetensi Dosen Menurut Undang-Undang https://stipgrahakaryamuarabuli an.ac.id/2018/05/17/kualifikasidan-kompetensi-dosenmenurut-undang-undang/ diakses tanggal 15 Agustus 2020

Farida Nurrafidah. Teori hubungan interpersonal.

https://www.academia.edu/1562 8154/teori_hubungan_interpers 
onal, diakses tanggal 15 Agustus 2020

Irma Surya. 2012. Kualitas Personal Dosen Pendidikan Bahasa Dan Sastra Indonesia Sebagai Agen Pembaharuan Pendidikan Dalam Pembelajaran Menulis vol 2 no. 22012 diakses tanggal 15 AGustus 2020

Nurlailis Saadah.2017. Komunikasi dan konseling. EGC. Jakarta

Sudijono,Anas 2010, Pengantar Statistik Pendidikan, PT. Raja Grafindo Persada, Jakarta

Yuni Kurniasih dan Anggorowati, 2017.

\footnotetext{
Keterampilan interpersonal : upaya menciptakan komunikasi efektif Journal of Health Studies, Vol. 1, No.1 1, No.1
}

Wayan Emi Lustinayanti. 2015. Kompetensi Dosen Dalam Konteks Keprofesian https://www.researchgate.net/pu blication/280037453_kompeten si_dosen_dalam_konteks_kepro fesian diakses tanggal 15 Agustus 2020 